\title{
Development of the foreign direct investments in the transitive economies: Example of Central-European Countries (CEC)
}

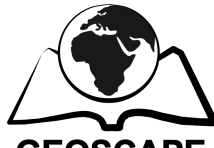

GEOSCAPE

\author{
Petr Hlaváček ${ }^{1 *}$ \\ ${ }^{1}$ University of J.E. Purkyně in Ústí nad Labem, Faculty of Social \\ and Economic Studies, Department of Regional and Local \\ Development, Moskevská 54, 40096 Ústí nad Labem, Czech \\ Republic \\ *petr.hlavacek@ujep.cz
}

\begin{abstract}
The paper focuses on the foreign direct investments (FDI) in the Central Europe and on the development changes among the individual countries. The paper follows from the work (Gauselmann et al. 2011) dealing with the development of the transient economies with focus on the role of the FDI. The objective of the paper is identification of the impact of the FDI on the economic growth and economic performance during the post-transformation era where differences among the countries at the beginning of the monitored period in 2000 and at the end of 2011 are evaluated based on data of United Nations Conference for Trade and Development. The development of FDI following 2000 was positively influenced by new system of the investment incentives for the foreign investors, accession of the countries to the European Union, it increased their credibility for foreign investors. High inflow of foreign direct investment ended with beginning of the economic crisis in 2008. Current trend in FDI is below its level before the economic crisis, and their amount increase only by few percent per year.
\end{abstract}

Key words: Foreign Direct Investments (FDI); transitive economies; Central Europe

Highlights for public administration, management and planning:

- the territorial differences in FDI inflow in Czech and Slovak regions are shown

- the interregional differences are growing due to higher FDI inflow to "strong" regions

- public policy should support localisation of investors in regions with lower economic performace

Received: 10 May 2015 - Received in revised form: 16 Jun 2015 - Accepted: 19 Jun 2015

\section{Introduction}

Early in the 1990s, the countries of the Central Europe were undeveloped compared to the countries of the Western Europe as far as the economy and industry is concerned, and their growth was associated with the need of high volume of the foreign direct investments (FDI). The post-socialistic countries in the Central Europe expected from the inflow of the foreign direct investments to accelerate the process of the privatization and economic transformation, to contribute to reduction of the economic impacts of the transformation, and to assist in the integration of the countries in the global economy (Hlaváček 2014; Myant 2014). For this reason, the inflow of the foreign direct investments became one of the basic conditions of the economic growth, and therefore the 
analysis of the foreign investments as the vehicle of the economic changes is very important. The localization decision making of the foreign investors in case of the countries of the Central Europe, as well as of the Czech Republic, was influenced by possibility of entering to the new markets, increasing their production efficiency thanks to relatively cheap privatized production capacity (Estrin et al. 2009) and the motivation to use cheaper but qualified workforce. Important was also size of the economies of the countries of the Central Europe and companies located in these countries (Carstensen, Troubal, 2004). These advantages of the countries of the Central Europe were to different extent sought after by specific needs of the entrepreneurship (Hlaváček et al. 2015) and their development strategies.

The result of the investment decision making of the foreign companies is uneven inflow of the foreign direct investments both with respect to the countries of the Central and Eastern Europe and the regional level where it could be noted that the foreign direct investments is reflection of a different potential of the countries or the regions. Despite the impacts of the foreign direct investments were beneficial for the economic development according to Benáček (2000), the foreign direct investments were originally characterized by rather weaker level of the integration with the local economic environment. This situation was gradually changed due to increased quality of production from the domestic companies and development of the sub-contractor relationships with the branches of the foreign investors already localized there. Therefore, the localization factors (Maier, Tödtling 1997) differentiated among the countries, regions, or cities (Sucháček 2013) have the key role in decision making on the placement of the new investments. The differences in the concentration of the foreign direct investments are reflected at the national level, even within each country, which is described by Toušek, Toušek (2003) or Hlaváček and Koutský (2011) in the example of the Czech Republic. Šipikal (2010) dealt with the regional deployment of the foreign direct investments in Slovakia.

The paper follows from the works (Próchniak 2001; Narula, Dunning, 2000; Gauselmann et al. 2011) dealing with the development of the transitive economies with focus on the role of the foreign direct investments in time of economic transformation.

\section{Research aims and methods}

The foreign direct investments are regarded as an indicator of the economic development of a national economy and a stimulus for its growth. The host country yet assumes that the foreign investor will contribute to increased competitiveness, creation of new jobs, transfer of the technologies, and new knowledge. In case of the post-communistic countries, accession to the Western developed markets and integration to the global economy were important as well. The foreign direct investments operate in the diversified manner at the level of the countries of the Central Europe, and this paper will therefore analyze the impact of the foreign direct investments in the selected countries of the Central Europe, more specifically in the Czech Republic, Hungary, Poland, Slovakia, and Slovenia in the context with development of the other macroeconomic indicators.

It could be noted for the needs of this paper, i.e. in relation with the foreign direct investments, that the commonly used indicators of the foreign investors in their decision about placing of their investments abroad will be the macroeconomic indicators and the framework of the public policy for support of the inflow of the foreign direct investments. The paper will be focused on comparison and analysis of the development trends in the field of the foreign direct investments with the main macroeconomic indicators, such as the level and growth of the gross domestic product, direct foreign investments and the development in volume of the foreign direct investments in relation to the gross domestic product. Considering availability of data, the underlying monitored period will be the development from 2002 to 2012.

\section{Development of FDI in context of the main macroeconomic indicators}

The development of the selected macroeconomic indicators points out to the development changes 
to the national economies that are also influenced by the inflow of the foreign direct investments. Fig. 1 illustrates gross domestic product growth per capita for the selected countries in current market prices.

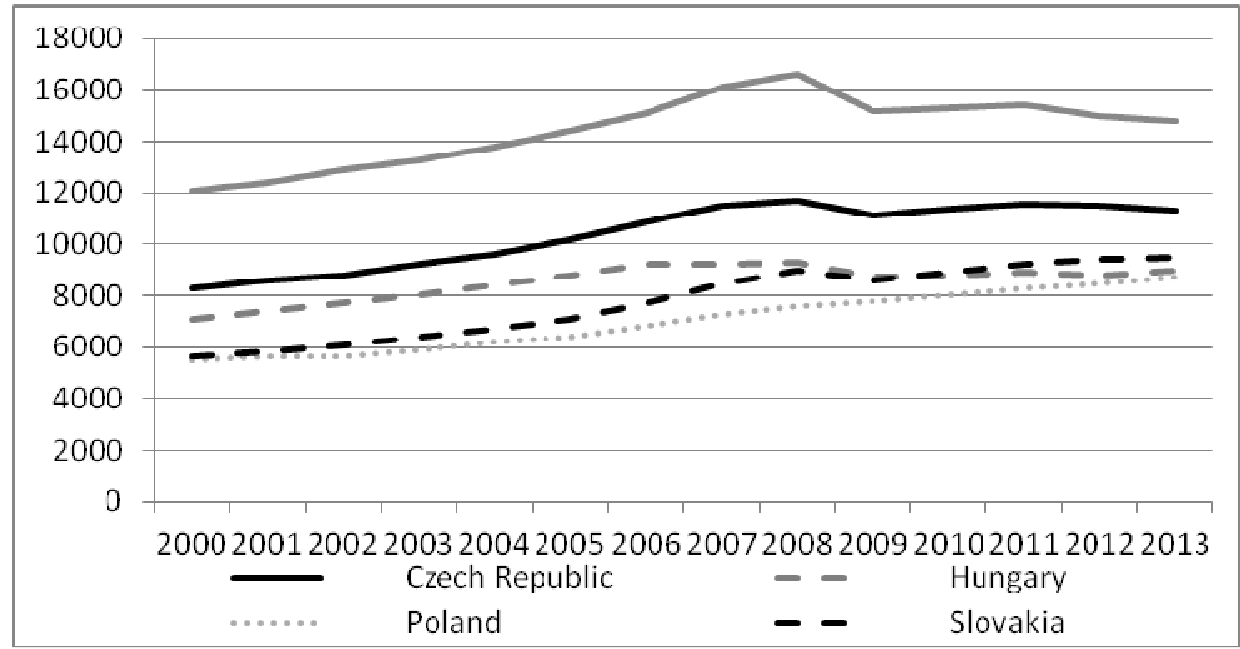

Fig. 1 - Development of Gross Domestic Product (GDP) per capita (in Euro). Source: own processing based on data from Eurostat

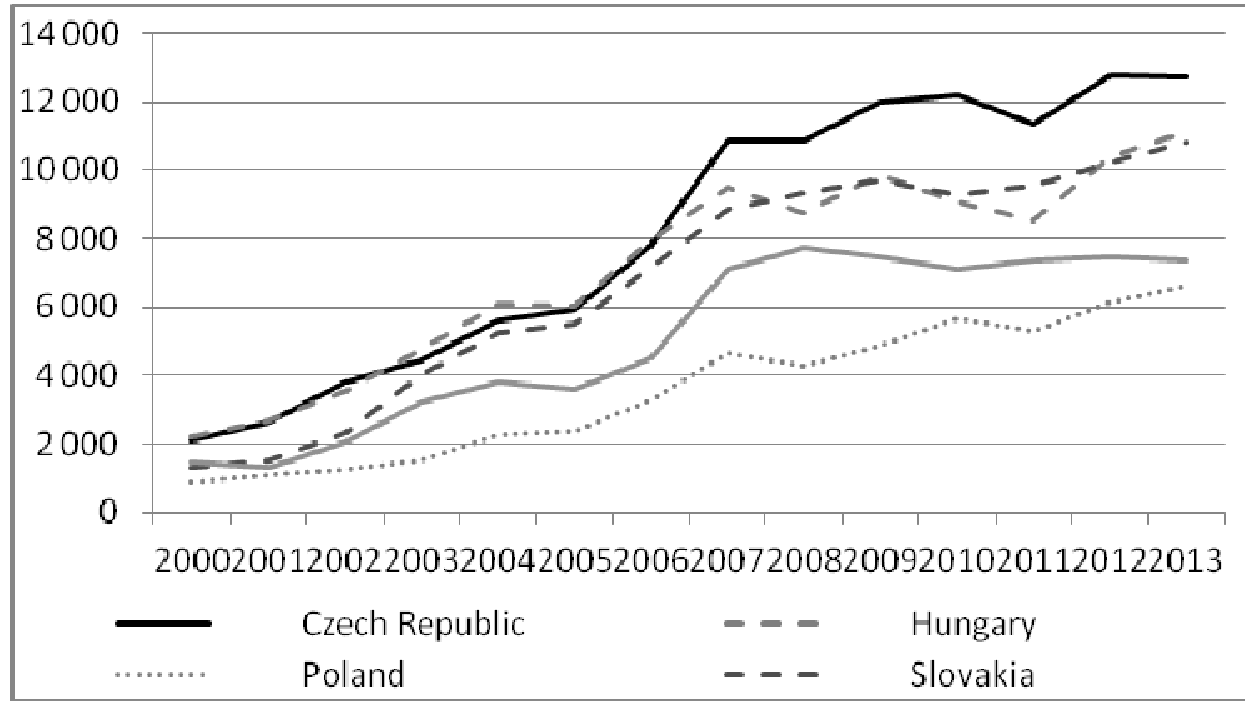

Fig. 2 - Development of the foreign direct investments (FDI) per capita in 2000-2013 (USD at current prices). Source: own processing based on data from UNCTAD

In long-term run, Slovenia is one of the countries with the highest gross domestic product per capita in the countries of the Central Europe. The jump increase in the gross domestic product per capita in the Czech Republic, Hungary, and Slovakia between 2004 and 2007 is attributed to the boom of the national economies with an important role of the foreign direct investments inflow supported by accession of the Central Europe countries to the European Union (Fig. 2).

The gross domestic product growth in Slovakia was, in addition, supported by economic reform after 2000. The Polish economy was more resistant to influences of the economic crisis. Hungary lost its position due to failure to implement the reforms needed. 
Table 1 provides another insight in the development of the gross domestic product illustrating the gross domestic product development in the pre-crisis era before 2008 and after the crisis between 2008 and 2013 (values in \%). It could be stated that especially growth of the gross domestic product was better than average growth in Slovakia. In the 1990s, Slovakia lagged behind the inflow of the foreign direct investments and at the economic growth level. Following the economic and political reforms late in the 1990s, huge inflow of the foreign direct investments and the economic growth were reported as illustrated in Tables 1 and 2. The growth in volume of the foreign direct investments and gross domestic product in this period was seen in all countries of the Central Europe during this era, and the total volume of the foreign direct investments grew in long-term run in most cases in the investigated economies.

Table 1 - Year-to-year average values of the gross domestic product development (in \%)

\begin{tabular}{llrl} 
& $\begin{array}{l}\mathbf{2 0 0 7 / 2 0 0 0} \\
\text { (year average) }\end{array}$ & $\begin{array}{l}\text { 2013/2008 } \\
\text { (year average) }\end{array}$ & $\begin{array}{l}\text { 2013/2008 } \\
\text { (year average) }\end{array}$ \\
\hline Czech Rep. & 5.1 & -0.6 & 2.6 \\
Hungary & 3.9 & -0.5 & 1.9 \\
Poland & 4.8 & 2.4 & 4.2 \\
Slovakia & 7.6 & 0.9 & 5.0 \\
Slovenia & 4.6 & -1.8 & 1.6
\end{tabular}

Table 2 - Growth of stock of the foreign direct investments in \%. Source: own processing based on data from UNCTAD.

\begin{tabular}{lrrrrrr} 
& $\mathbf{2 0 0 7 / 2 0 0 0}$ & $\begin{array}{l}\text { 2007/2000 } \\
\text { (year average) }\end{array}$ & $\mathbf{2 0 1 3 / 2 0 0 8}$ & $\begin{array}{l}\mathbf{2 0 1 3 / 2 0 0 8} \\
\text { (year average) }\end{array}$ & $\begin{array}{l}\mathbf{2 0 1 3 / 2 0 0 0} \\
\text { 2013/2008 } \\
\text { (year average) }\end{array}$ \\
\hline Czech Rep. & 415.0 & 51.9 & 16.9 & 2.8 & 506.2 & 36.2 \\
Hungary & 324.2 & 40.5 & 27.3 & 4.6 & 363.7 & 26.0 \\
Poland & 423.5 & 52.9 & 53.3 & 8.9 & 589.4 & 42.1 \\
Slovakia & 582.3 & 72.8 & 15.9 & 2.7 & 692.3 & 49.5 \\
Slovenia & 389.3 & 48.7 & -5.2 & -0.9 & 414.4 & 29.6
\end{tabular}

Table 3 Growth of stock of foreign direct investment (FDI) in relation to gross domestic product (in \%). Source: own processing based on data from UNCTAD, Eurostat

\begin{tabular}{lrrrrrr} 
& $\mathbf{2 0 0 7 / 2 0 0 1}$ & $\begin{array}{l}\mathbf{2 0 0 7 / 2 0 0 1} \\
\text { (year average) }\end{array}$ & $\mathbf{2 0 1 2 / 2 0 0 8}$ & $\begin{array}{l}\mathbf{2 0 1 2 / 2 0 0 8} \\
\text { (year average) }\end{array}$ & \begin{tabular}{r}
$\mathbf{2 0 1 2 / 2 0 0 1}$ \\
\multicolumn{2}{l}{$\mathbf{2 0 1 2 / 2 0 0 1}$} \\
(year average)
\end{tabular} \\
\hline Czech Rep. & 27.0 & 4.5 & 26.6 & 5.3 & 47.8 & 4.0 \\
Hungary & 23.2 & 3.9 & 31.0 & 6.2 & 50.8 & 4.2 \\
Poland & 76.4 & 12.7 & 34.2 & 6.8 & 113.2 & 9.4 \\
Slovakia & 115.3 & 19.2 & 57.5 & 11.5 & 153.4 & 12.8 \\
Slovenia & 92.0 & 15.3 & 31.3 & 6.3 & 115.6 & 9.6
\end{tabular}




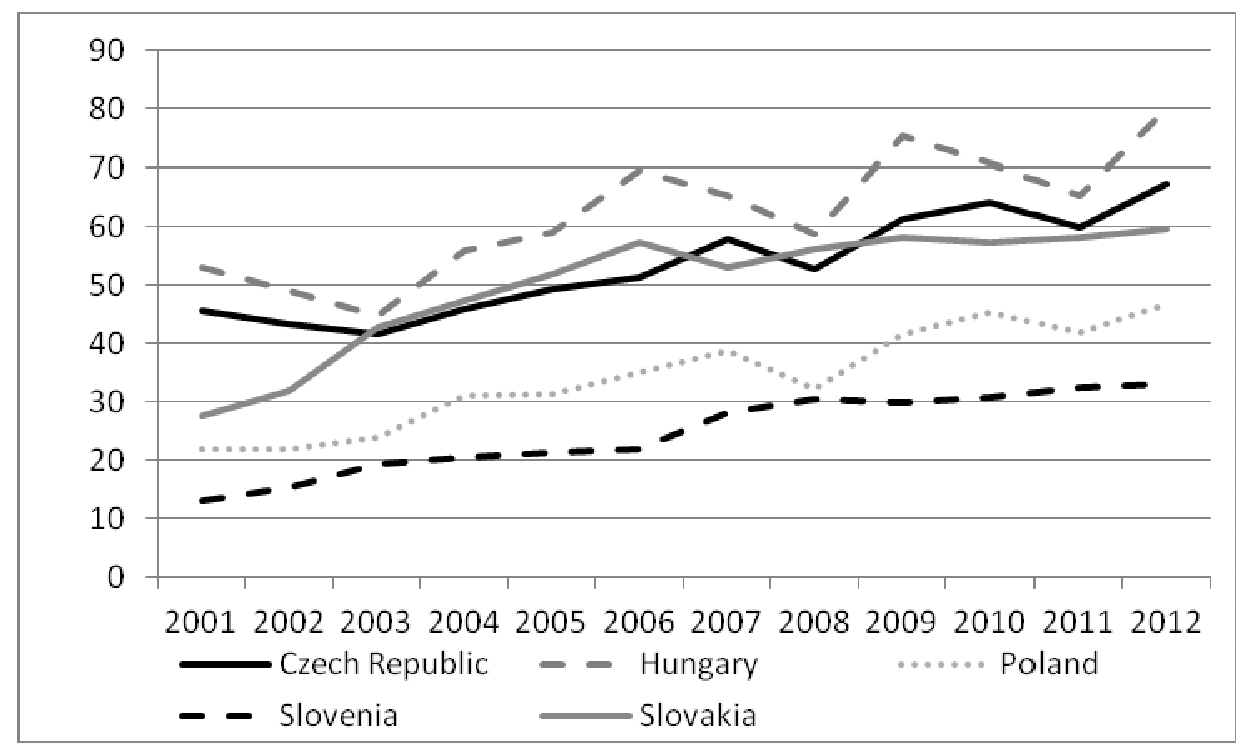

Fig. 3 - Stock of foreign direct investment (FDI) in relation to gross domestic product. Source: own processing based on data from UNCTAD, Eurostat.

The stock of total foreign direct investments expressed as per-cent of the gross domestic product is shown in Fig. 3. The indicator measures the intensity of the investment integration of the national economy within the world economy. The foreign direct investments includes both original implemented investment as well as all subsequent capital transactions, e.g. in the form of the re-invested profits. The data is compared in per-cent as of the gross domestic product level to compare the Central European countries and to evaluate the openness level of the economies of the countries for foreign direct investments.

The Fig. 3 illustrates comparison of gross domestic product per capita and volume of foreign direct investments per capita shows important differences between individual countries. The highest amount of total foreign direct investments in relation to the amount of the gross domestic product is achieved in Hungary where it achieves almost $80 \%$. The Czech Republic keeps high level in the long-term run to which Slovakia has approached tightly over the last years. The highest increase in the foreign direct investments in the economy in relation to the gross domestic product between 2001 and 2012 was reported for Slovakia followed by Slovenia and Poland.
Considering higher saturation of the foreign direct investments early in the period in question, the Czech and Hungarian economies reported slower increase. In the period after 2008 the pace of growth of the foreign direct investments is further reduced; in case of Slovakia it drops to $11.5 \%$, whereas similar drops are reported also from Poland and Slovenia where the growth of the volume in the foreign direct investments dropped by $3 \%$. Although reduced growth in the volume of the foreign direct investments was originally reported in the Czech Republic and Hungary, both economies maintained in average stable growth of the foreign direct investments between 2008 and 2013, and Hungary even reported slightly higher when compared to previous years. Despite different trends in each country, it could be noted that development of the foreign direct investments in the economy in relation to the gross domestic product corresponds to the differences in the inflow of the foreign direct investments directed to each economy.

The different paces of the growth are also influenced by the total volume of the investments in the era before 2000 when the countries with the economies started up earlier by the privatization process opened more to the inflow of the foreign direct investments, and 
therefore they reported higher volume of the realized foreign direct investments per capita as well.

In most cases, long-term increase in the volume of the foreign direct investments in the reviewed economies was reported between 2001 and 2012. The highest increments of the foreign direct investments were seen in the pre-crisis era when the foreign direct investments volume increased especially in case of Slovakia. Slovenia and Poland also reported higher inflow of foreign direct investments.

The development was caused by several factors; very important of which was that the economies were oscillating in the boom phase, increased their credibility by accession to the European Union, and at the same time they have created a system of the investment incentives for the foreign investors, which made the area of the Central Europe more attractive and contributed to the highest inflow of the foreign investors.

The reduced inflow of the foreign direct investments is also related with gradual change in the perception of the Central European countries, and the investments looking for quality of human resources, activities in the field of R\&D and technological development. Repatriation of the generated profit or reduced volume of the reinvestments of the foreign investors within each country contributed to the drop.

\section{Discussion and conclusions}

Following break-up of the Eastern Bloc, fundamental political and economic changes were seen, accompanied by opening of the economies and markets to the foreign investors. Following the economic and political reforms early in the 1990s, the inflow of the foreign direct investments started with the privatization of the large state enterprises in all transitive economies during the 1990s. The development of the inflow of the foreign direct investments in the countries can be described as a dynamic process, influenced to a higher extent by ongoing economic reforms, and development of the economic cycle of the European economies.

The area of the Central Europe has become more attractive for Foreign Investments and more integrated into global production chains and the global economy. The advantage of the Czech Republic, Poland, Hungary, Slovakia, and Slovenia is favourable geographic location towards the countries of the Western Europe and relatively quality traffic infrastructure for good accessibility to the Western markets. With respect to the localization benefits, the comparative one against the Western countries remains in the form of cheap and quality educated workforce. Despite fluctuating development over recent years, it can be said based on the development of the monitored factors that domestic as well as the foreign direct investments helped to the economic growth of the Central European countries.

The role of the foreign direct investments will be still important in the next years due to their contribution to the economic growth and growth of the competitiveness of the Central Europe in the global economy, and will reinforce the economic integration of the countries of the former Eastern Bloc into the global production chains. According to Tun et al. (2012), Poelhekke, van der Ploeg (2009), sustaining of the inflow of the foreign direct investments will be important to provide corresponding quality of the institutional structures and rules, as well as the effective public administration.

\section{Acknowledgements}

The research is based on support within specific university grant research conducted at the Jan Evangelista Purkyně University in Ústí nad Labem.

\section{References}

Benáček V (2000) Př́mé zahraniční investice v české ekonomice: praxe, teorie a aplikace. Politická ekonomie, 1: 7-24.

Carstensen K, Troubal F (2004) Foreign direct investment in Central and Eastern European countries: a dynamic panel analysis. Journal of Comparative Economics, 32: 3-22.

Estrin S, Hanousek J, Kočenda E, Švejnar J (2009) The Effects of Privatization and Ownership in Transition Economies. Journal of Economic Literature, 2009, 47(3): 699-728.

Gauselmann A, Knell M, Stephan J (2011) What drives FDI in Central-Eastern Europe? Evidence from the 
IWH-FDI-Micro database. Post-Communist Economies, 23(3): 343-357.

Hlaváček P (2014) The Phenomenon of Foreign Direct Investment in Central Europe. In: Koustký J, Raška $\mathrm{P}$, Dostál $\mathrm{P}$, Herrschel $\mathrm{T}$ (eds) Transitions in Regional Science - Regions in Transitions: Regional Research in Central Europe. Wolters-Kluwer, Prague, pp. 135-141.

Hlaváček P, Koutský J (2011) The Polarization Tendencies in Localization of Foreign Direct Investments in the Czech Republic. 10th International Conference of Liberec Economic Forum, Liberec, 186-194.

Hlaváček P, Žambochová M, Siviček T (2015) The Influence of the Institutions on Entrepreneurship Development: Public Support and Perception of Entrepreneurship Development in the Czech Republic. Amfiteatru Economic, 17(38): 408-421.

Maier G, Tödtling F (1997) Regionálna a urbanistická ekonomika. Bratislava, Elita.

Myant M (2014) Transforming Economies and Societies in Central Europe. In: Koustký J, Raška P, Dostál P, Herrschel T (eds) Transitions in Regional Science - Regions in Transitions: Regional Research in Central Europe. Wolters-Kluwer, Prague, pp. 119-134.

Narula R, Dunning JH (2000) Industrial Development, Globalization and Multinational Enterprises. Development Studies, 28(2): 141-167.
Poelhekke S, van der Ploeg F (2009) Foreign direct investment and urban concentrations: unbundling spatial lags. Journal of Regional Science, 49(4): 749-775.

Próchniak M (2001) Determinants of economic growth in Central and Eastern Europe: the global crisis perspective. Post-Communist Economies. 23(4): 449-468.

Sucháček J (2013) Urban Potential for Investment Attraction in the Czech Republic. In: Jiřičková E, Knapková A, Pastuszková E (eds) Finance and the Performance of Firms in Science, Education, and Practice 2013, Zlin: Tomas Bata University, 2013, 718-727.

Šipikal M (2010) Priame zahraničné investície v ekonomike Slovenska. In: WOKOUN, R, TVRDOŇ, J. a kol. Přímé zahraniční investice a regionální rozvoj. 1st ed. Praha: Oeconomica, 47-64.

Toušek V, Tonev P (2003) Foreign Direct Investment in the Czech Republic (with the emphasis on border regions). Acta Universitatis Carolinae, Praha, XXXVIII(1), 445-447.

Tun Y, Azman-Saini W, Law S (2012). International Evidence on the link between Foreign Direct Investment and Institutional Quality. Inzinerine Ekonomika-Engineering Economics, 2012, 23(4): 379-386. 